\title{
In vivo study of the general toxic properties of a probiotic preparation based on lactic and propionic acid microorganisms
}

\author{
C Rishat S. Mukhammadiev, ${ }^{+}$Rinat S. Mukhammadiev, \\ Anna M. Tremasova, ${ }^{*}$ and Lenar R. Valiullin \\ Laboratory of Probiotic Preparations and Enzymes. Federal Center for Toxicological, Radiation and \\ Biological Safety. Scientific Town-2. Kazan, 420008. Tatarstan Republic. Russia. \\ Phone: +7 (843) 239-53-20. E-mail:vnivi@mail.ru
}

\begin{abstract}
*Supervising author; ${ }^{+}$Corresponding author Keywords: probiotic, lactic acid and propionic acid microorganisms, general toxic properties, in vivo.
\end{abstract}

\begin{abstract}
In this paper, the study of general toxic properties of probiotic preparation based on lactic and propionic acid microorganisms was carried out. Establishment of class of acute toxicity of studied liquid form of the drug was based on fundamental document OECD 423 "Acute Toxic Class Method" (2001). In the study of acute toxicity, the physiological state, growth rate, morbidity and safety, changes in the parenchymal organs of laboratory animals were assessed. The results of determining the acute toxicity of probiotic preparation showed that a single oral administration of it in various doses did not lead to the death of animals during the experimental period, all the main indicators of their vital activity were within the physiological norm and did not differ from the control. The condition of all groups of animals remained satisfactory, no violations of the functional activity of the digestive and urinary systems were revealed. Body temperature, respiration and heart rate of the animals were within normal limits. Shown $100 \%$ safety of animals, no toxic signs at 1000 -fold increase in the dose of the liquid form of probiotic were not observed. The study of the irritating effect of the drug was carried out on the mucous membrane of the right eye of animals, applying one drop of the sample under the upper eyelid, on the anterior segment of the eye. Consideration of the possible reaction of the mucous membrane of the experimental eye, eyelid and cornea was carried out 15 minutes (fast reaction) after exposure to the drug suspension and after 24, 48 hours of observation (delayed-type hypersensitivity). Evaluation of the effect of the probiotic drug on the conjunctiva showed that the suspension of strains of microorganisms does not cause irritation, both immediately after instillation and throughout the entire study period.
\end{abstract}

\section{References}

[1] A.S. Mukhammadiev, R.S. Mukhammadiev, R.S. Mukhammadiev, L.R. Valiullin. Isolation and analyse of morphological and biochemical properties of new strains of lactic acid bacteria perspective for creation Vet. vrach. 2020. No.3. P.39-46. (russian)

[2] T.I. Usikova. Etiology of diseases of the gastrointestinal tract of young cattle. In the collection: Ecology of Southern Siberia and adjacent territories. Materials of the XXII International Scientific SchoolConference of Students and Young Scientists. 2018. P.88-91. (russian)

[3] A.A. Kazeem, A.A. Olayinka, N.A. Collins. Probiotics in animal husbandry: applicability and associated risk factors. Sustainability. 2020. Vol.12. No.3. P.1087-1099. DOI: 10.3390/su12031087

[4] H. Yirga. The use of probiotics in animal nutrition. J. Prob. Health. 2015. Vol.3. No.2. P.132-142. DOI: 10.4172/2329-8901.1000132

[5] L.S. Celiberto, R. Bedani, E.A. Rossi, D.C. Cavallini. Probiotics: The scientific evidence in the context of inflammatory bowel disease. Crit. Rev. Food Sci. Nutr. 2017. Vol.57. No.9. P.1759-1768. DOI: $10.1080 / 10408398.2014 .941457$

[6] Мухаммадиев Р.С., Мухаммадиев Р.С., Валиуллин Л.Р., Бирюля В.В., Скворцов Е.В. Ферментативная активность ксиланаз и целлюлаз пробиотических штаммов Bacillus subtilis. Bem. врач. 2019. №3. C.19-23.

R.S. Mukhammadiev, R.S. Mukhammadiev, L.R. Valiullin, V.V. Biryulya, E.V. Skvortsov. Enzymatic activity of xylanases and cellulases of probiotic strains of Bacillus subtilis. Vet. vrach. 2019. No.3. P.1923. (russian) 
[7] R.S. Mukhammadiev, R.S. Mukhammadiev, A.S. Mukhammadieva. Study of the nature of intergeneric interactions of new strains of probiotic microorganisms. In the collection: Innovative developments and digitalization in the agro-industrial complex of the Russian Federation. Proceedings of the International Scientific and Practical Conference dedicated to the 50th anniversary of the Tatar NIIAHP - a separate structural subdivision of the FRC KazSC RAS and the 75th anniversary of the Kazan Scientific Center of the Russian Academy of Sciences. 2020. P.244-248. (russian)

[8] J. Chen, Q. Wang, C.M. Liu, J. Gong. Issues deserve attention in encapsulating probiotics: Critical review of existing literature. Crit. Rev. Food Sci. Nutr. 2017. Vol.57. No.6. P.122801238. DOI: 10.1080/10408398.2014.977991

[9] A. Terpou, A. Papadaki, I.K. Lappa, V. Kachrimanidou, L.A. Bosnea, N. Kopsahelis. Probiotics in food systems: significance and emerging strategies towards improved viability and delivery of enhanced beneficial value. Nutrients. 2019. Vol.11. No.7. P.1591-1623. DOI: 10.3390/nu11071591

[10] C. Meng, C. Bai, T.D. Brown, L.E. Hood, Q. Tian. Human gut microbiota and gastrointestinal cancer. Genom. Proteom. Bioinf. 2018. Vol.16. No.1. P.33049. DOI: 10.1016/j.gpb.2017.06.002

[11] E.V. Skvortsov, R.S. Mukhammadiev, R.S. Mukhammadiev, L.R. Valiullin. The effect of a probiotic preparation based on Bacillus subtilis on the microbial community of the intestine of rats. Bulletin of Biotechnology and Physicochemical Biology. Yu.A. Ovchinnikov. 2019. Vol.15. No.1. P.30-35. (russian)

[12] E.V. Skvortsov, R.S. Mukhammadiev, R.S. Mukhammadiev, L.R. Valiullin, D.A. Valiullina. Obtaining emulsified probiotic preparation Bacillus subtilis and its effect on the intestinal microflora of laboratory rats. Sci. notes of Kazan State Acad. of Vet. Med. named after N.E. Bauman. 2020. Vol.241. No.1. P.187-192. (russian)

[13] G.R. Gibson, M.B. Roberfroid. Dietary modulation of the human colonic microbiota: Introducing the concept of prebiotics. J. Nutr. 1995. Vol.125. P.140101412. DOI: 10.1093/jn/125.6.1401

[14] L. Valiullin, R. Mukhammadiev, A. Solovyova, E. Skvortsov, R. Mukhammadiev, D. Valiullina, N. Kasanova. Reducing the risks of environmental pollution by agents of biological origin. J. Environ. Manag. Tour. 2020. Vol.11. No.3. P.555-562. DOI:10.14505//jemt.v11.3(43).07

[15] FAO. 2016. Probiotics in animal nutrition - Production, impact and regulation by Yadav S. Bajagai, Athol V. Klieve, Peter J. Dart and Wayne L. Bryden. Editor Harinder P.S. Makkar. FAO Animal Production and Health Paper No.179. Rome. Available at: http://www.fao.org/3/a-i5933e.pdf. Accessed October 31, 2017.

[16] Food and Agriculture Organization and World Health Organization Expert Consultation. Evaluation of health and nutritional properties of powder milk and live lactic acid bacteria. Córdoba, Argentina: Food and Agriculture Organization of the United Nations and World Health Organization; 2001. [cited 2005 September 8]. Available from: ftp://ftp.fao.org/es/esn/food/probio_report_en.pdf.

[17] R.S. Mukhammadiev, R.S. Mukhammadiev, V.V. Biryulya, E.V. Skkvortsov, I.I. Idiyatov, L.R. Valiullin. Study of the in vitro cytotoxicitytesting of lactic and propionic acid bacteria. Vet. vrach. 2019. No.4. P.17-20. (russian)

[18] Guidance document OECD Test No.423 "Acute Oral Toxicity - Acute Toxic Class Method", 14 p. DOI: 10.1787 / 20745788

[19] GOST 31928-2013 Probiotic medicinal products for veterinary use. Methods for the determination of probiotic microorganisms. Moscow: Standartinform. 2014. 31p.

[20] GOST 31926-2013 Medicines for veterinary use. Methods for determining harmlessness. Moscow: Standartinform. 2014. 34p.

[21] GOST 12.1.007-76 Occupational Safety Standards System (SSBT). Harmful substances. Classification and general safety requirements (with Amendments No. 1, 2). Moscow: Standartinform. 2007. 10p.

[22] GOST R 51232-98 Drinking water. Moscow: Standartinform. 2008. 39p.

[23] GOST 34566-2019 Complete feed for laboratory animals. Moscow: Standartinform. 2020. 10p.

[24] A.N. Mironov. Guidelines for conducting preclinical studies of drugs. Part 1. Moscow: Grifi K. 2012. 944p. (russian)

[25] V.P. Fisenko. Guidelines for experimental (preclinical) study of new pharmacological. Moscow: Remedium. 2000. 398p. (russian)

[26] Order of the Ministry of Health of Russia dated 01.04.2016 No. 199 n "On approval of the Rules of Good Laboratory Practice". URL: http://docs.cntd.ru/document/420350679

[27] Guidelines for determining the toxic properties of drugs used in veterinary medicine and animal husbandry. Book: Veterinary drugs. Directory. Moscow: Agropromizdat. 1988. P.239-289. (russian)

[28] Rish.S. Muhammadiev, Rin.S. Muhammadiev, T.V. Bagaeva, L.R. Valiullin, A.P. Glinushkin. Influence of different carbon and nitrogen sources on the production of xylanases by Bipolaris 
IN VIVO STUDY OF THE GENERAL TOXIC PROPERTIES OF A PROBIOTIC PREPARATION BASED... sorokiniana. Achievements Sci. Technol. AIC. 2019. Vol.33. No.1. P.41-44. DOI: 10.24411/0235-24512019-10110

[29] E.V. Skvortsov, Rish.S. Muhammadiev, Rin.S. Muhammadiev, L.R. Valiullin. Erythromycin effect on the intestinal microbial community of rats. Uch Zap Kazan Univer. Ser. Estes Nauki. 2020. Vol.162. No.1. P.112-122. DOI: 10.26907/2542-064X.2020.1.112-122. (russian) 